\title{
Comparative Analysis of the Effectiveness of Regulation of Aeration Depending on the Quantitative Characteristics of Treated Sewage Water
}

\author{
Myroslav Malovanyy, Vira Shandrovych, Andriy Malovanyy, and Igor Polyuzhyn
}

Lviv Polytechnic National University, 12 Stepan Bandera Street, Lviv 79013, Ukraine

Correspondence should be addressed to Myroslav Malovanyy; mmal@lp.edu.ua

Received 21 December 2015; Revised 14 May 2016; Accepted 8 June 2016

Academic Editor: Anuska Mosquera-Corral

Copyright (C) 2016 Myroslav Malovanyy et al. This is an open access article distributed under the Creative Commons Attribution License, which permits unrestricted use, distribution, and reproduction in any medium, provided the original work is properly cited.

\begin{abstract}
Monitoring of work of the aeration tanks of operating town treatment plants is done. Based on the obtained results a conclusion has been drawn that sewage water is improperly treated from ammonium nitrogen. The velocity of the aeration process, depending on the concentration of dissolved oxygen and ammonium nitrogen, is investigated. The obtained investigation data became the basis for modeling the aeration process in industrial conditions depending on the required initial concentration of ammonium nitrogen.
\end{abstract}

\section{Introduction}

At present, the most widely used methods for wastewater treatment are based on biological processes. Among different configurations of biological treatment technologies the most applied one is the activated sludge process. Depending on treatment quality requirements the systems which are based on activated sludge can be designed to treat wastewater from either only organic pollutants or both organic pollutants and nutrients (nitrogen and phosphorus). Activated sludge process has the following advantages that are especially revealed in household sewage water treatment: their simple construction, reliable work (when treating stable, nontoxic, and moderately polluted sewage water), possibility of use for treatment of the sewage water of different composition, and so forth [1].

The treatment effectiveness in aerated tanks, state, and oxidizing ability of the active sludge are determined by certain conditions, namely, composition and properties of sewage water, hydrodynamic stirring conditions, correlation of the amount of supplied sewage and viable sludge, aeration strategy, temperature and active reaction of environment, availability of power supply elements, and presence of activators and inhibitors of the process [2].
One of the important parameters that significantly influence the effectiveness of treatment is the aeration system design and control. At the same time, aeration of wastewater requires significant energy input and is often one of the biggest constituents of the total energy need of a plant. While aeration need in systems working at low sludge retention time (SRT) and high organic loading is still rather low at about $0.5 \mathrm{~g} \mathrm{O}_{2} / \mathrm{g}$ BOD removed due to higher yield and lower mineralization of influent organics, the activated sludge processes which achieve full nitrification require up to $2 \mathrm{~g}$ $\mathrm{O}_{2} / \mathrm{g}$ BOD removed [3]. Aeration can consume up to $60 \%$ of the total energy consumption of a plant.

Thus, the inadequate amount of air supplied into the zone of biological reactions with participation of microbiological associations of active sludge decreases the treatment efficiency. The excess of air does increases the effectiveness but causes a significant increase of the power consumption for aeration. To ensure the adequate treatment many plants are still operated with higher than necessary concentration of dissolved oxygen in the activated sludge basins.

Therefore, aeration system optimization can potentially result in significant treatment cost reduction. A large number of studies were dedicated to improving existing and developing new aeration strategies. 


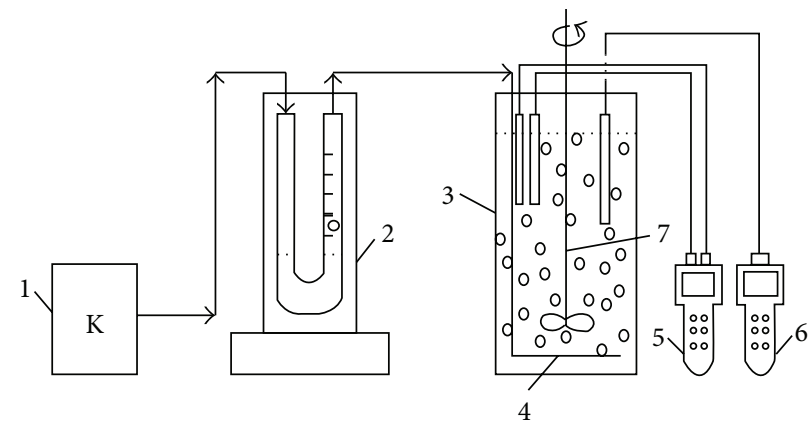

FIGURE 1: Experimental setup: 1: compressor; 2: rheometer; 3: bioreactor, 4: aeration diffuser; 5: pH/ISE $/ \mathrm{mB} /{ }^{\circ} \mathrm{C}-\mathrm{meter}$ sensIon ${ }^{\mathrm{TM}} 2$; 6: oxygen analyzer sensIon $6^{\mathrm{TM}} ;$ 7: electric mixer.

While change of aeration intensity by maintaining stable dissolved oxygen (DO) concentration is a standard practice nowadays [4], variable DO concentration during different loading conditions and different DO level along the plug flow activated sludge line are getting more popular due to proven long-term cost reduction [5]. Adapting of aerated volume based on the load to a plant was also proposed [6].

The most advanced aeration strategies make use of one or several ammonium sensors to predict or verify the aeration requirement. In these systems ammonium content in inflow (in feedforward systems) or outflow (in feedback systems) controls the DO set-points in an activated sludge line [7]. While there were many simulation studies performed aiming at predicting energy savings from the ammonium-based control systems $[8,9]$, most of them used literature-based kinetic coefficients to describe the system performance.

This study aims at evaluation of ammonium-based aeration control system by determining the most important kinetic coefficients of nitrification process using real wastewater and biomass of Lviv wastewater treatment plant followed by a simulation study with a model, which uses the determined coefficients.

\section{Materials and Methods}

2.1. Batch Experiments on Nitrification Rate Determination. Two types of test were done in this part of the study in order to determine influence of ammonium and dissolved oxygen (DO) concentration on nitrification activity.

Investigations on ammonium concentration influence were made with application of the experimental setup presented in Figure 1. The change of ammonium concentration was measured during one hour while the DO concentration kept constant in the reactor. Synthetic wastewater in these experiments was prepared using tap water supplemented with ammonium chloride to reach the desired ammonium nitrogen concentration.

Activated sludge collected at Lviv wastewater treatment plant \#2 (WWTP 2) was then added to reach a desired mixed liquor suspended solids concentration. All the tests were performed at the MLSS concentration of $2 \mathrm{~g} / \mathrm{L}$. After that the concentration of ammonium was measured for 1 hour with every 10 min while the concentration of dissolved oxygen was kept constant at desired level. For each corresponding value of the dissolved oxygen concentration four batch experiments were performed with initial ammonium concentrations of about 30, 20, 10, and $5 \mathrm{mg} / \mathrm{L}$. These experiments were carried out in order to determine the nitrification activity at different ammonium concentration in wastewater treatment system.

The air supply rate was measured by the rheometer RDS6. The air was supplied by the Atman AT-8500 compressor.

The tests on DO influence were done using the same synthetic wastewater as with the tests described above. The wastewater was aerated to saturation with oxygen. Then activated sludge was added and the decrease of DO concentration in the test bottle mixed with a magnetic mixer was measured. The decrease of the DO concentration was recalculated for ammonium consumption and this data was used to calculate the activity at different DO concentrations.

\subsection{Investigation of the Aeration Process in Field Conditions.} The concentration of DO and ammonium was measured at all of the treatment trains of the plant and compared to the readings of the stationary treatment plant sensors and the results of oxygen measuring by Winkler's method for certain samples in the outlet of the aeration tank, obtained in chemical-bacteriological laboratory of the wastewater treatment plant.

The biological step of the WWTP consists of 6 plug flow activated sludge basins and secondary clarification basins. Every activated sludge basin consists of three passes. DO measurement is carried out by the Endress+Hauser company equipment, namely, two gauges Oximax COS 41 located at the inlet of the second pass and the aeration tank outlet. The gauges were fixed stationarily and immersed at a depth of $50 \mathrm{~cm}$ and connected to recording devices Liquisys M COM $223 / 253$. Except for the dissolved oxygen concentration the wastewater temperature is measured as well.

2.3. Aeration Process Modeling. The obtained dependence of nitrification activity at different ammonium and dissolved oxygen concentration was used as a basis for the developed mathematical model of the process of ammonium oxidation in a conventional elemental cell of the wastewater treatment plant. 


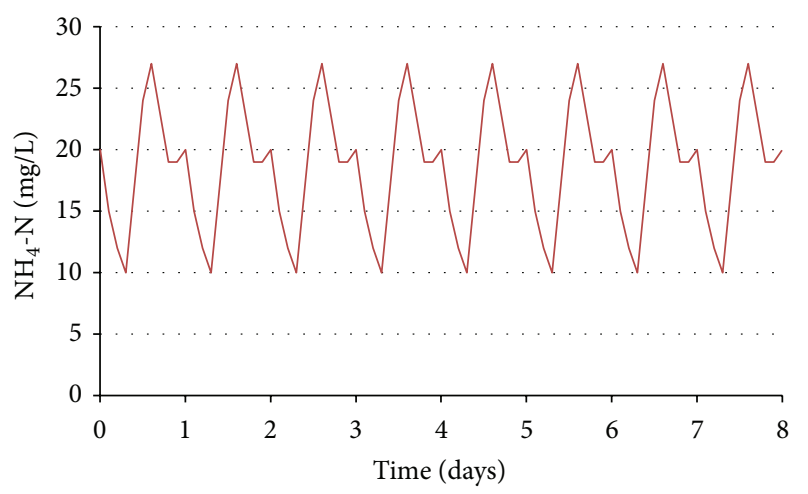

FIGURE 2: Variation of the ammonium nitrogen concentration at the inlet of a wastewater treatment plant assumed in the model (the data is based on [4]).

Dependence of the process velocity on the concentration of dissolved oxygen was described by the Monod equation [4]:

$$
r=r_{\max } * \frac{[\mathrm{DO}]}{K_{0}+[\mathrm{DO}]},
$$

where $r$ is velocity of microorganisms growth; [DO] is dissolved oxygen concentration; $r_{\max }$ is maximum velocity of microorganisms growth; $K_{0}$ is half-saturation concentration.

In this case the dependence of the process velocity on ammonium nitrogen concentration was modeled as a first-order dependence with the $k_{N}$ coefficient determined experimentally:

$$
r=k_{N} * C(N)
$$

where $C(N)$ is concentration of ammonium nitrogen; $k_{N}$ is experimentally determined coefficient (see Section 3.2).

General equation of the process is written as [4]

$$
\frac{d N}{d t}=Q \cdot \frac{N_{\mathrm{inl}}-N}{V}-k_{N} \cdot N \cdot \frac{[\mathrm{DO}]}{K_{0}+[\mathrm{DO}]} \cdot X,
$$

where $X$ is concentration of active sludge in the reactor (assumed to be equal to $3500 \mathrm{mg} / \mathrm{L}$ ); $Q$ is the wastewater inflow rate, which has a variable value for each of the tested conditions; $V$ is reactor volume (assumed to be $1 \mathrm{~m}^{3}$ ); $N$ is concentration of ammonium nitrogen in the reactor $(\mathrm{mg} / \mathrm{L})$; $N_{\text {inl }}$ is concentration of ammonium nitrogen at the reactor inlet.

The ammonium oxidation rate in the described model changes, respectively, to the variation of ammonium nitrogen concentration in municipal wastewater during a day. For modeling the dependence of ammonium nitrogen concentration at the reactor inlet was assumed in the form presented in Figure 2.

Modeling of the process according to (3) was carried out by the method of numerical differentiation using Excel program. Calculation step was chosen to be 0.001 days. Calculation of the air consumption was done according to generally known relations described in [4], using constants from Table 1.
TABLE 1: Values of constants for calculation of air consumption.

\begin{tabular}{lc}
\hline Constant & Values \\
\hline$\alpha$ & 0.6 \\
$\beta$ & 0.98 \\
Temperature of water and air & $25^{\circ} \mathrm{C}$ \\
Theoretical concentration of air saturation & $8.2 \mathrm{mg} / \mathrm{L}$ \\
Reactor depth & $4 \mathrm{~m}$ \\
Atmospheric pressure & $100 \mathrm{kPa}$ \\
Factor F & 0.9 \\
Aerators effectiveness & $30 \%$ \\
\hline
\end{tabular}

Aeration process was modeled for three cases: (1) for high concentrations of ammonium nitrogen; (2) for low concentrations of ammonium nitrogen; (3) for very low concentrations of ammonium nitrogen.

In all the cases the modeling process was realized for four types of aeration control: with constant value of dissolved oxygen at 1, 2, and $3 \mathrm{mg} / \mathrm{L}$ and variable value of dissolved oxygen, depending on the difference between the ammonium concentration in the reactor and the set-point. The DO set-points for the ammonium-based controlled strategy were optimized for every of the studied cases separately as described in Section 3.3.

2.4. Analytical Methods. Concentration of dissolved oxygen (DO) was determined with the portable oxygen analyzer Hach sensIon6. Ammonium $\left(\mathrm{NH}_{4}{ }^{+}\right)$concentration was measured by the portable $\mathrm{pH} / \mathrm{ISE} / \mathrm{mV} /{ }^{\circ} \mathrm{C}$-meter Hach sensIon 2 with the ion-selective electrode ELIS-121 $\mathrm{NH}_{4}$ and the reference electrode ESr-10103. The meters were calibrated using the same synthetic wastewater which was used in the test in order to account for matrix effects.

\section{Results and Discussion}

3.1. Results of Monitoring. Results of monitoring the operation of Lviv treatment plant, WWTP 2, are presented in Table 2. It is clear that the values of the stationary oxygen analyzer and the portable meter differ and in some cases this difference is significant. However, there is a certain correlation between the DO measured by the gauge of the treatment plant and our results obtained in laboratory conditions, presented in Figure 3. The best data fit is observed for potentiodynamic measurements and the results of chemicobacteriological laboratory, in which measurement of DO is done by Winkler's method (Figure 4).

The most probable explanation of this difference is the instability of readings of the treatment plant stationary device DO due to the following reasons: membranes in the Clark voltammetric gauges can be polluted with active sludge; penetration of air bubbles on the membrane can cause a sudden rise in the value of DO concentration and poor calibration.

Besides, the poor performance of the meters can be caused by membrane aging and rupture. In this case it is 
TABLE 2: Concentration of dissolved oxygen in aerated tanks of WWTP 2.

\begin{tabular}{|c|c|c|c|c|c|c|c|c|c|c|c|c|}
\hline \multirow{3}{*}{$\begin{array}{l}\text { Measurement } \\
\text { method }\end{array}$} & \multicolumn{12}{|c|}{ Aerated tanks } \\
\hline & \multicolumn{2}{|c|}{ Number 1} & \multicolumn{2}{|c|}{ Number 2} & \multicolumn{2}{|c|}{ Number 3} & \multicolumn{2}{|c|}{ Number 4} & \multicolumn{2}{|c|}{ Number 5} & \multicolumn{2}{|c|}{ Number 6} \\
\hline & 2nd pass & Outlet & 2nd pass & Outlet & 2nd pass & Outlet & 2nd pass & Outlet & 2nd pass & Outlet & 2nd pass & Outlet \\
\hline $\begin{array}{l}\text { Treatment plant } \\
\text { sensor }\end{array}$ & 0.18 & 0.25 & 9.9 & 6.04 & 5.69 & 0.24 & 8.55 & 4.01 & 6.3 & 0.29 & 0.32 & 0.19 \\
\hline $\begin{array}{l}\text { Oxygen } \\
\text { analyzer data }\end{array}$ & 0.44 & 0.41 & 3.67 & 2.33 & 3.4 & 0.54 & 2.69 & 1.73 & 3.15 & 2.6 & 0.11 & 0.37 \\
\hline $\begin{array}{l}\text { Laboratory } \\
\text { measurement } \\
\text { results }\end{array}$ & - & 0.96 & - & 3.12 & - & 2.24 & - & 1.68 & - & 2.56 & - & 0.37 \\
\hline
\end{tabular}

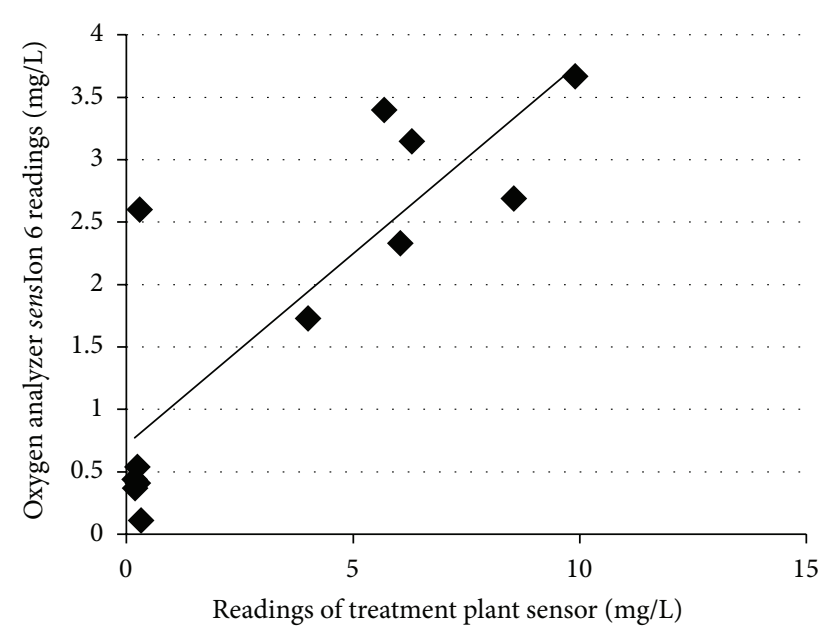

FIGURE 3: Correlation of DO concentration measured by treatment plant sensors and the portable meter.

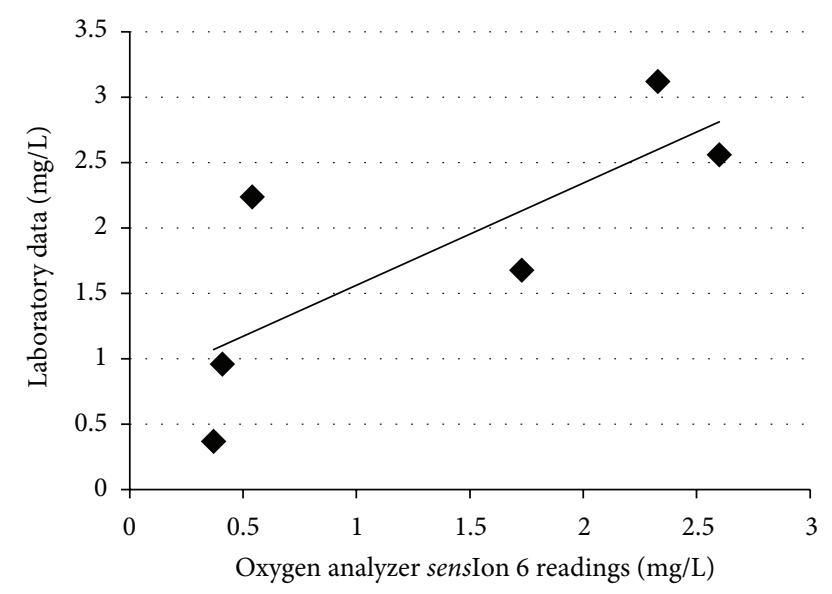

FIGURE 4: Correlation of the potentiodynamic measurement by the stationary probes and results of chemical-bacteriological laboratory.

worth using modern DO optical gauges that have some advantage to compare with the Clark devices.

3.2. Results Obtained in Laboratory Conditions. Results of laboratory investigations on evaluating the nitrification activity (expressed as $\mathrm{mg} \mathrm{N} / \mathrm{g}$ sludge per hour) with respect to

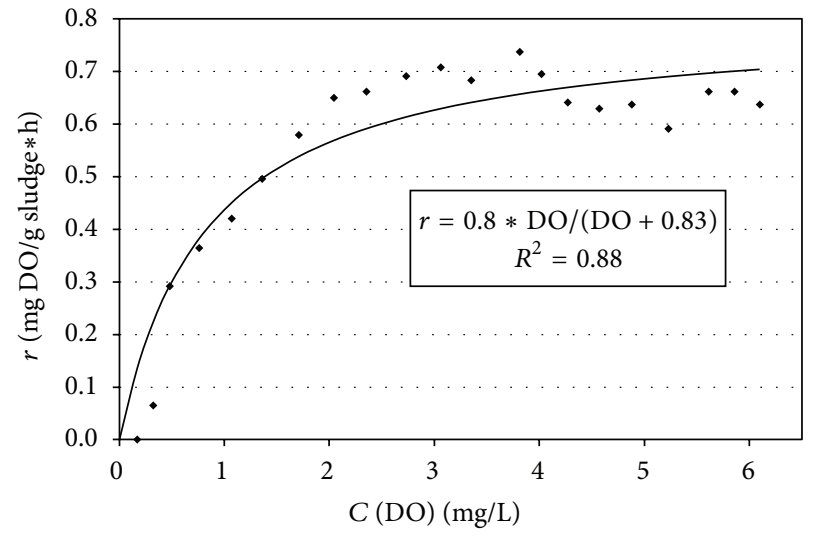

FIGURE 5: Approximation of the nitrification rate, depending on dissolved oxygen concentration, using the Monod kinetics.

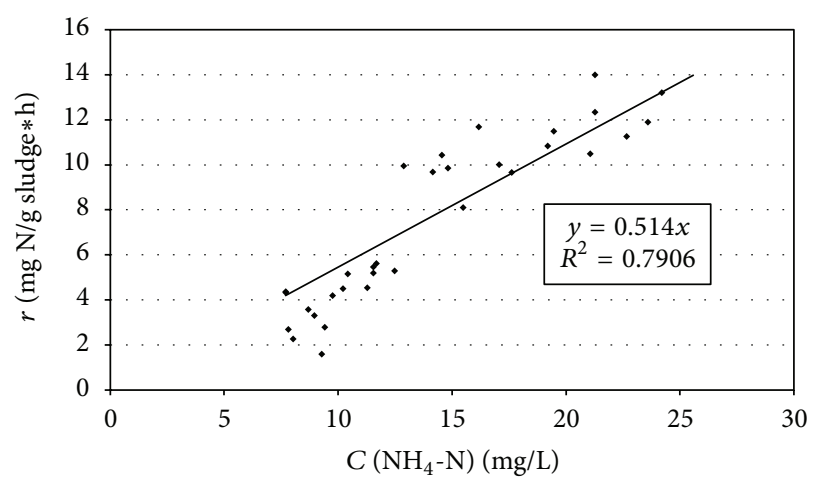

FIgURE 6: Approximation of the nitrification rate, depending on ammonium nitrogen concentration, using a linear dependence.

DO concentration and ammonium nitrogen concentration are presented in Figures 5 and 6, respectively.

The dependence on oxygen concentration could be fitted well with the Monod equation (see (1)). The determined values of constants are $r_{\max }=0.8 \mathrm{mg} / \mathrm{L}$ and $K_{0}=0.83 \mathrm{mg} / \mathrm{L}$ with the determination coefficient $R^{2}=0.88$. The obtained approximation curve is presented in Figure 5.

Concerning the dependence of the process velocity on ammonium nitrogen concentration, in case of a perfect system, it should also follow the Monod kinetics. But in the 
TABLE 3: Change of DO concentration based on ammonium setpoints.

\begin{tabular}{lccc}
\hline $\begin{array}{l}\text { Ammonium set-point, mg/L } \\
\text { Delta } \mathrm{NH}_{4}<\end{array}$ & 7.5 & $\begin{array}{c}3.5 \\
\text { DO concentration }\end{array}$ & 1.8 \\
\hline-1 & 3 & 3 & 3 \\
-0.75 & 2.2 & 2.5 & 2.5 \\
-0.5 & 1.7 & 1.9 & 1.9 \\
-0.25 & 1.2 & 1.2 & 1.2 \\
0 & 0.8 & 0.8 & 0.8 \\
0.25 & 0.7 & 0.7 & 0.7 \\
0.5 & 0.6 & 0.6 & 0.6 \\
0.75 & 0.5 & 0.5 & 0.5 \\
1 & 0.4 & 0.4 & 0.4 \\
1 & 0.3 & 0.3 & 0.3 \\
\hline
\end{tabular}

real system with the dissolved oxygen consumption not only for ammonium ions oxidizing, but also for other oxidizing processes and with nitrogen concentration gradient in flocs the experimental points decline from the Monod dependence (see Figure 5). The data could be, however, fit with a linear function (see (2)). The kinetic coefficient $k_{N}$ was determined to be $0.54 \mathrm{~L} /(\mathrm{g}$ sludge $* \mathrm{~h})$.

\subsection{Mathematic Modeling}

3.3.1. Optimization of Ammonium-Based Control Strategy. In the ammonium-based aeration control the DO was changed in steps based on the difference between the modeled ammonium concentration and ammonium set-point based on the defined steps as in Table 3.

The DO set-points were optimized for the three cases in order to get the lowest possible air consumption and at the same time have the average ammonium concentration in the outlet at approximately the same level as in the strategy with the stable DO concentration of $1 \mathrm{mg} / \mathrm{L}$. The obtained DO setpoints for the tree cases are the same for low ad medium content of ammonium in the bioreactor and are somewhat lower in the case of higher ammonium content.

3.3.2. The Aeration Process Modeling for High Concentrations of Ammonium Nitrogen. Process modeled for high concentrations of ammonium nitrogen is presented in Figures 7-11 and in Table 4. The ammonium set-point was set to $7.5 \mathrm{mg} / \mathrm{L}$ in the ammonium-based aeration controller.

The simulations showed that the variation in ammonium content is the highest when the DO concentration is high. Low DO values give lower effluent ammonium variations but also higher average ammonium content in the treated wastewater. Aeration is more efficient at lower DO content which gives lower specific aeration requirement.

3.3.3. The Aeration Process Modeling for Low Concentrations of Ammonium Nitrogen. Process modeled for high concentrations of ammonium nitrogen is presented in Figures 12-16

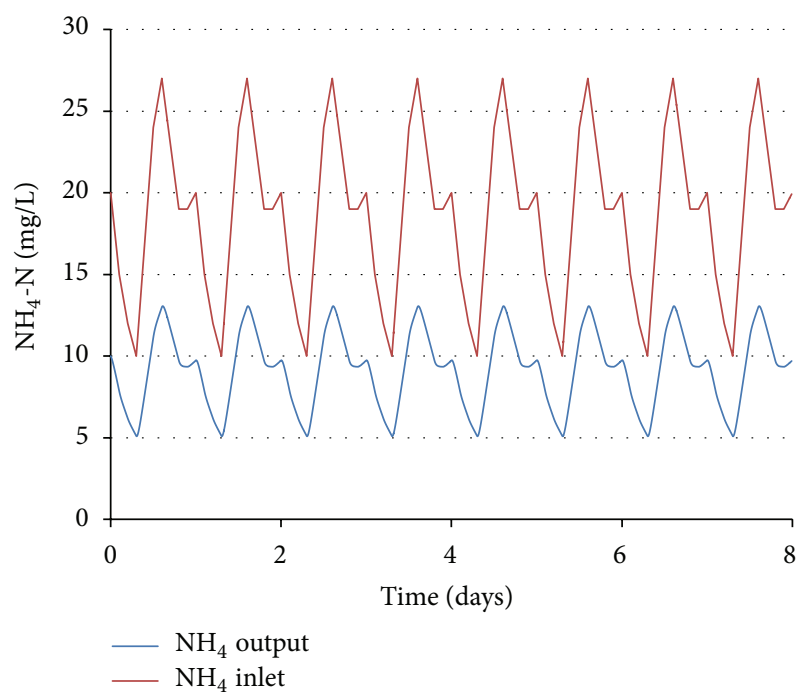

Figure 7: Nitrification process at DO concentration equal to 1.

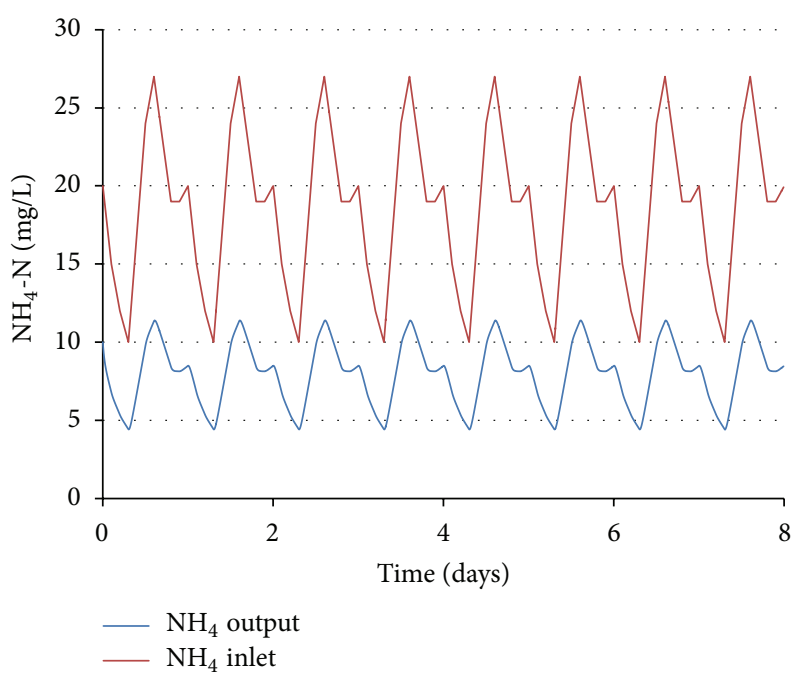

Figure 8: Nitrification process at DO concentration equal to 2.

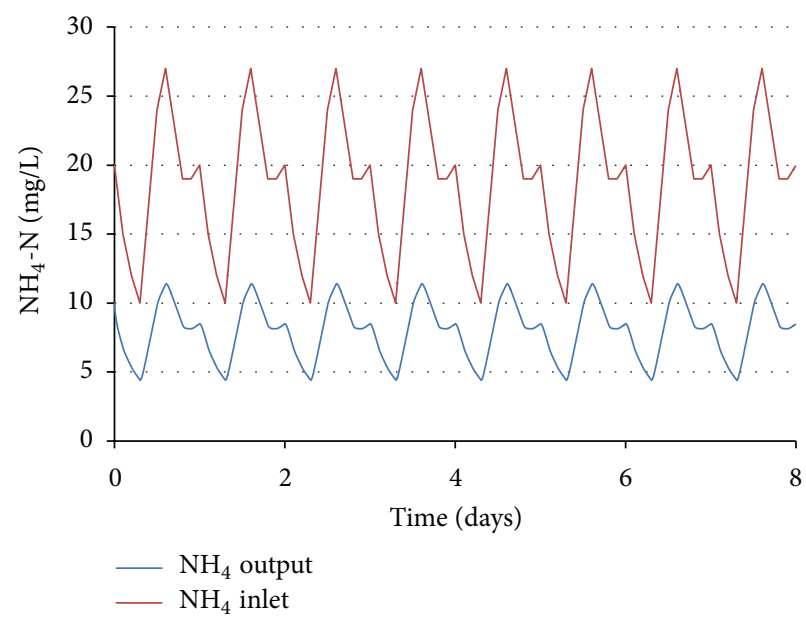

FIgURE 9: Nitrification process at DO concentration equal to 3. 
TABLE 4: Summarized averaged values for high concentrations of ammonium nitrogen.

\begin{tabular}{lcccc}
\hline & $\mathrm{DO}=1 \mathrm{mg} / \mathrm{L}$ & $\mathrm{DO}=2 \mathrm{mg} / \mathrm{L}$ & $\mathrm{DO}=3 \mathrm{mg} / \mathrm{L}$ & Ammonium set-point $=7.5 \mathrm{mg} / \mathrm{L}$ \\
\hline Oxidized nitrogen, g N/d & 227 & 255 & 267 & 246 \\
Nitrogen at the reactor outlet, g N/d & 220 & 191 & 180 & 200 \\
Air consumption, $\mathrm{m}^{3} / \mathrm{d}$ & 21 & 27 & 33 & 27 \\
Specific air consumption, $\mathrm{m}^{3} / \mathrm{kg} \mathrm{N}$ & 93 & 106 & 123 & 110 \\
\hline
\end{tabular}

TABLE 5: Summarized averaged values for low concentrations of ammonium nitrogen.

\begin{tabular}{lcccc}
\hline & $\mathrm{DO}=1 \mathrm{mg} / \mathrm{L}$ & $\mathrm{DO}=2 \mathrm{mg} / \mathrm{L}$ & $\mathrm{DO}=3 \mathrm{mg} / \mathrm{L}$ & Ammonium set-point $=3.5 \mathrm{mg} / \mathrm{L}$ \\
\hline Oxidized nitrogen, $\mathrm{g}$ N/d & 90 & 94 & 96 & 90 \\
Nitrogen at the reactor outlet, g N/d & 22 & 18 & 16 & 22 \\
Air consumption, $\mathrm{m}^{3} / \mathrm{d}$ & 8.3 & 10.0 & 11.8 & 8.6 \\
Specific air consumption, $\mathrm{m}^{3} / \mathrm{kg} \mathrm{N}$ & 93 & 106 & 123 & 95 \\
\hline
\end{tabular}

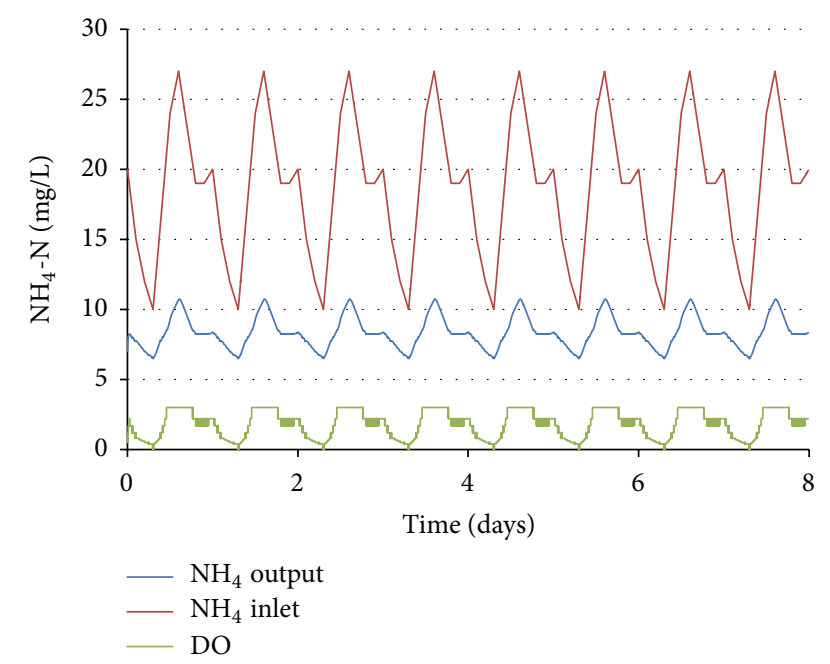

FIGURE 10: Nitrification process ammonium nitrogen set-point of $7.5 \mathrm{mg} / \mathrm{L}$.

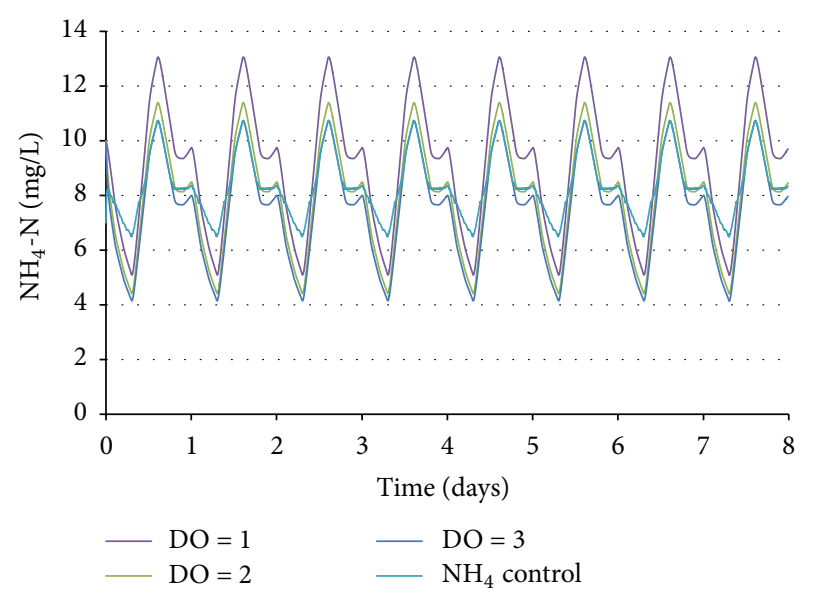

FIGURE 11: Summarized results of modeling for high concentrations of ammonium nitrogen.

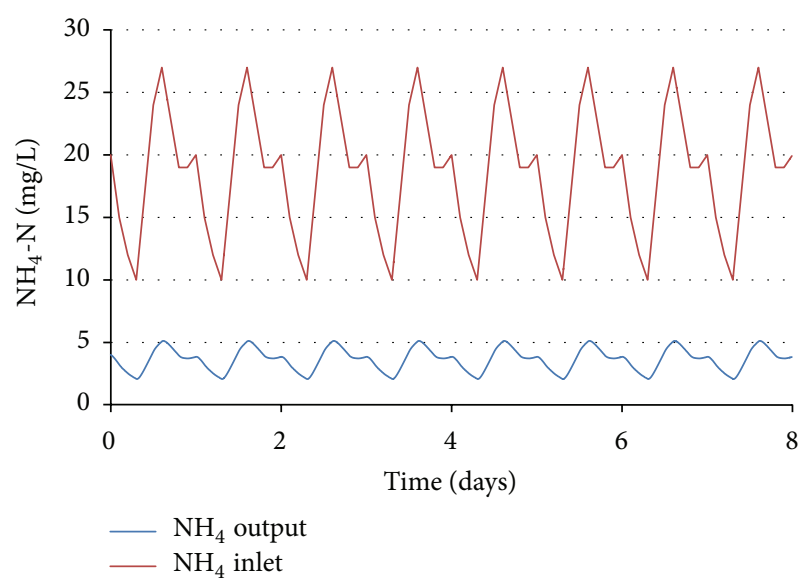

FIGURE 12: Nitrification process for DO concentration equal to 1.

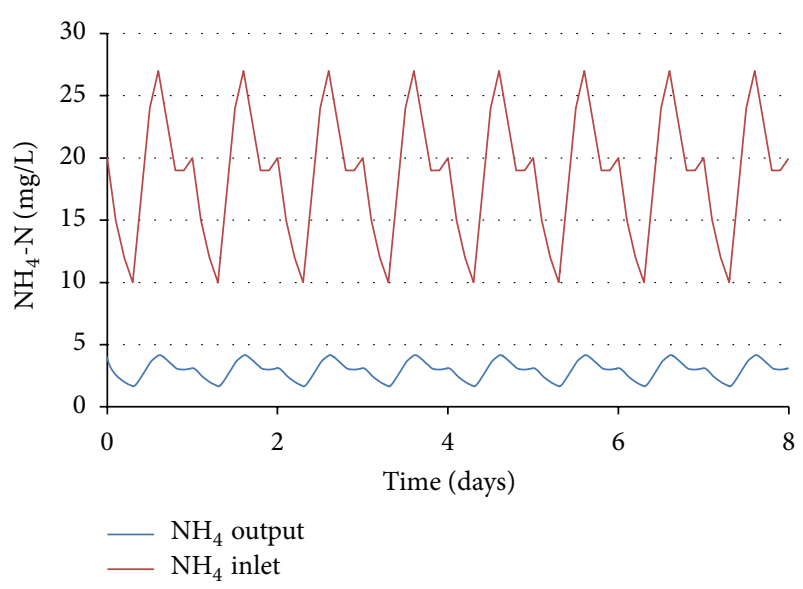

FIGURE 13: Nitrification process for DO concentration equal to 2 .

and in Table 5. The ammonium set-point was set to $3.5 \mathrm{mg} / \mathrm{L}$ in the ammonium-based aeration controller.

Similar pattern of ammonium concentration was observed even in this case. Relative variation of ammonium 
TABLE 6: Summarized averaged values for very low concentrations of ammonium nitrogen.

\begin{tabular}{lcccc}
\hline & $\mathrm{DO}=1 \mathrm{mg} / \mathrm{L}$ & $\mathrm{DO}=2 \mathrm{mg} / \mathrm{L}$ & $\mathrm{DO}=3 \mathrm{mg} / \mathrm{L}$ & Ammonium set-point $=1.8 \mathrm{mg} / \mathrm{L}$ \\
\hline Oxidized nitrogen, g N/d & 6.0 & 4.8 & 4.3 & 6.0 \\
Nitrogen at the reactor outlet, g N/d & 50 & 51 & 51 & 50 \\
Air consumption, $\mathrm{m}^{3} / \mathrm{d}$ & 4.6 & 5.4 & 6.3 & 4.7 \\
Specific air consumption, $\mathrm{m}^{3} / \mathrm{kg} \mathrm{N}$ & 93 & 106 & 123 & 95 \\
\hline
\end{tabular}

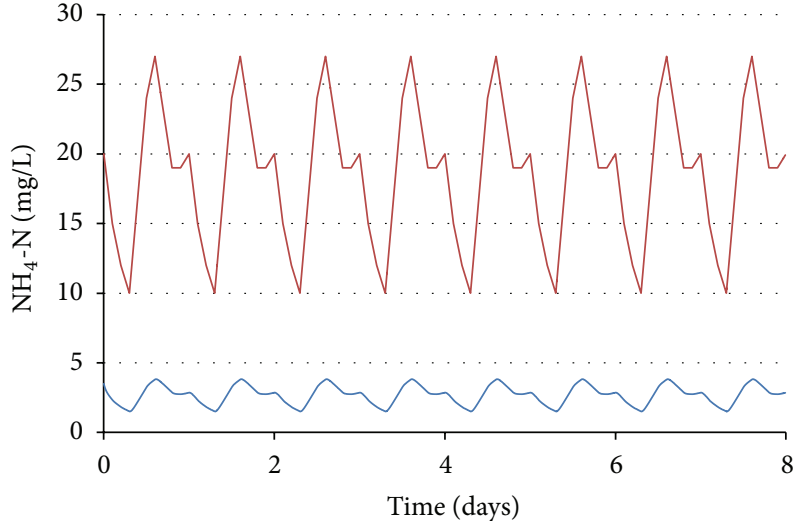

$-\mathrm{NH}_{4}$ output

FIGURE 14: Nitrification process for DO concentration equal to 3.

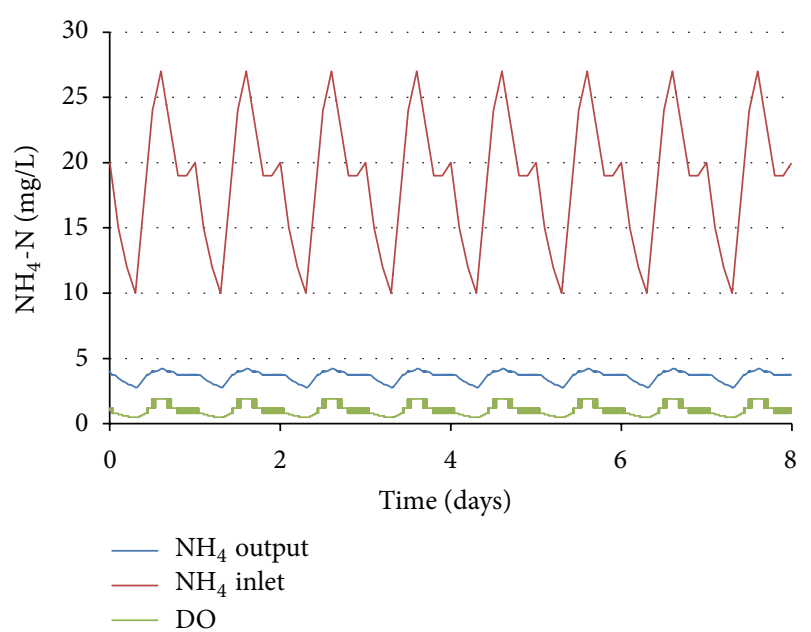

FIGURE 15: Nitrification process ammonium nitrogen set-point of $3.5 \mathrm{mg} / \mathrm{L}$

concentration was the same as the previous case but the absolute values were lower which is due to lower bacterial activity at lower ammonium concentrations.

3.3.4. The Aeration Process Modeling for Very Low Concentrations of Ammonium Nitrogen. Process modeled for very low concentrations of ammonium nitrogen is presented in Figures 17-21 and in Table 6.

The ammonium set-point was set to $1.8 \mathrm{mg} / \mathrm{L}$ in the ammonium-based aeration controller.

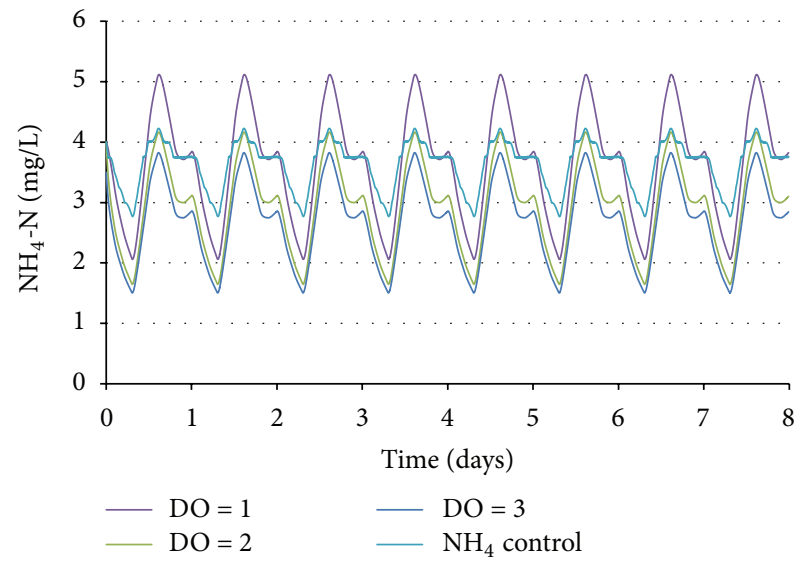

FIGURE 16: Summarized results of modeling for low concentrations of ammonium nitrogen.

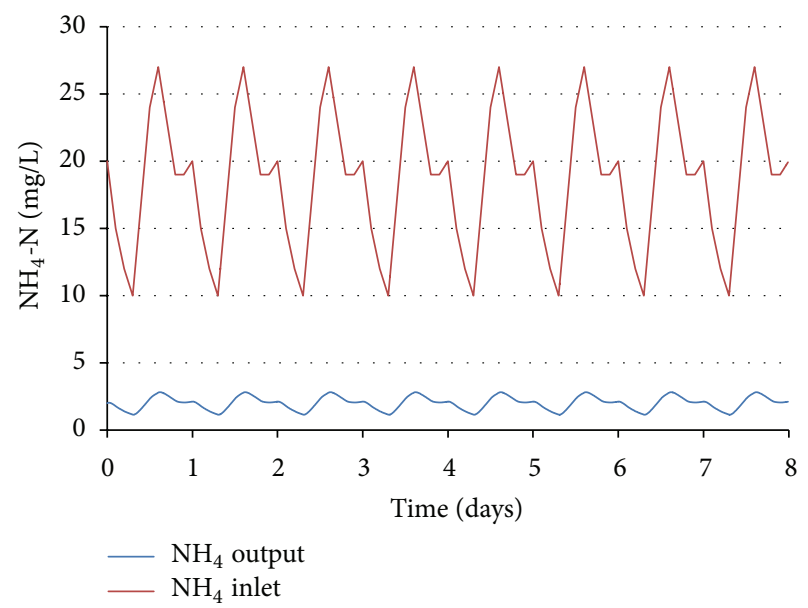

FIGURE 17: Nitrification process for DO concentration equal to 1.

The results of this case were similar to the relations observed for the previous case. It confirmed that the ammonium control is effective in stabilizing the effluent ammonium concentration at all the required treatment levels.

3.3.5. Aeration Strategies Comparison. The process of ammonium oxidation in a conventional cell of activated sludge was modeled. The modelling results show that the same nitrogen removal is reached with lower air consumption when a constant value of dissolved oxygen is maintained comparing to ammonium-based aeration control. However, in the control strategy with the stable DO one needs to predict 


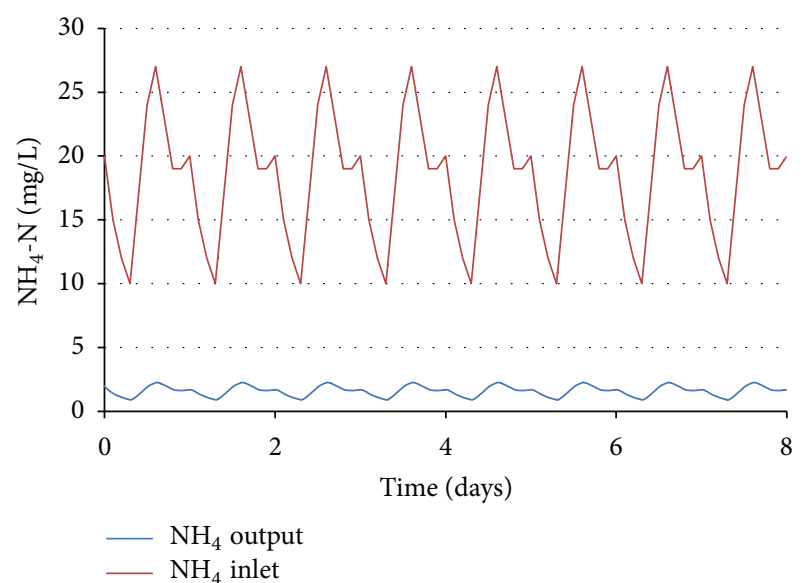

Figure 18: Nitrification process for DO concentration equal to 2.

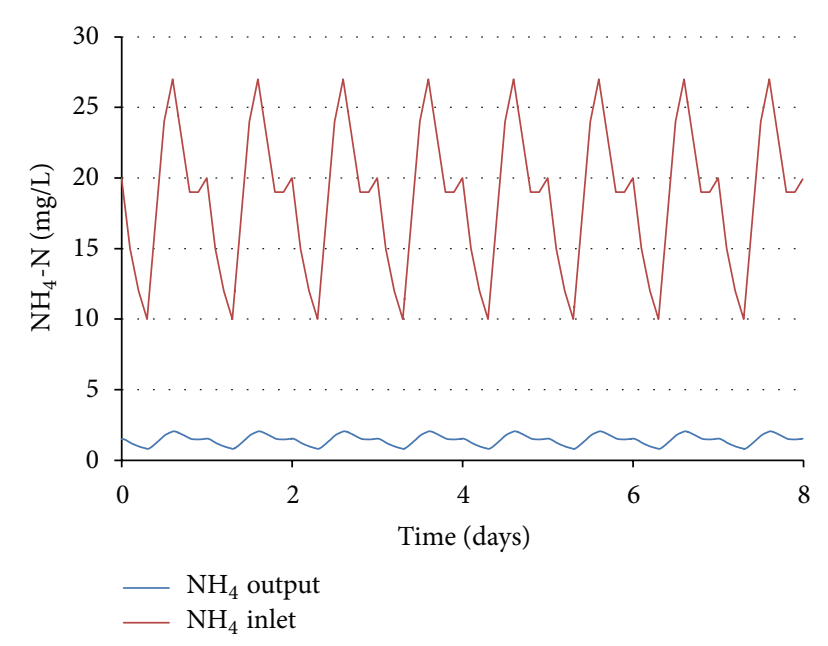

Figure 19: Nitrification process for DO concentration equal to 3.

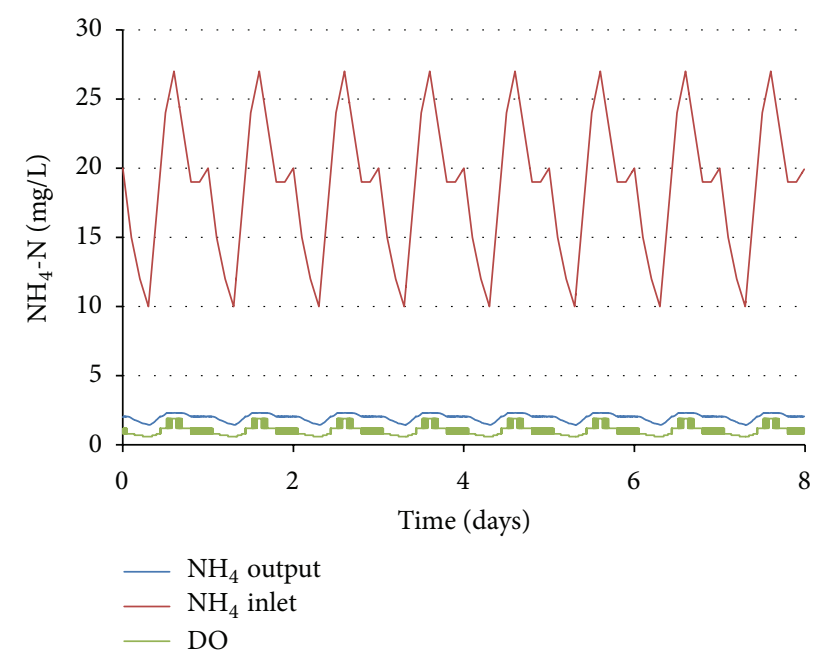

FIGURE 20: Nitrification process ammonium nitrogen set-point of $1.8 \mathrm{mg} / \mathrm{L}$.

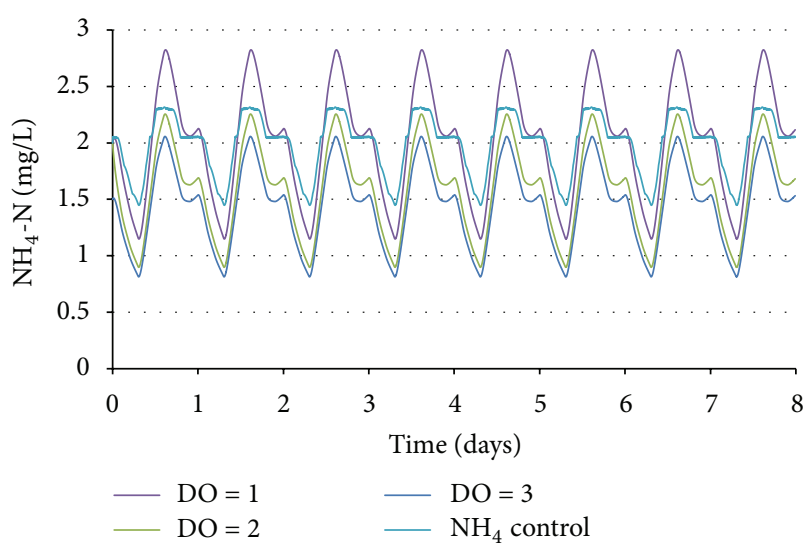

FIGURE 21: Summarized results of modeling for very low concentrations of ammonium nitrogen.

the incoming load so that the right DO concentration could be chosen.

The results of modeling show that with the ammoniumbased control the fluctuation of the outlet ammonium concentration is 2-3 times lower comparing to the stable DO strategy.

The use of ammonium concentration to control aeration allows DO content to change automatically and guarantees not only the required level of treatment but also a stable nitrogen concentration in the sewage water at the outlet of the aerator. Since even a short-term discharge with the increased concentration of ammonium can significantly affect the environment, such type of control provides the improvement of the level of environmental safety.

\section{Conclusions}

Analysis of the data of aeration tanks effectiveness monitoring at Lviv treatment plant showed that the operation of the aeration tanks at WWTP 2 is not effective enough and needs improvement. This improvement would include the change of the air supply strategy to the one where the control signal is formed based on the ammonium ions concentration and not on the DO concentration.

In order to quantify the effects of the new control system a mathematic model of an activated sludge reactor with nitrification process was developed based on the kinetic coefficients which were obtained experimentally. The model can predict the performance of a reactor at different inflow rates and incoming ammonium concentrations under different aeration strategies. The strategies include both stable DO level and stepwise regulation of the DO level based on the ammonium concentration. The developed model was tested and the results show that the ammonium-based control is superior to the control strategy with the stable DO concentration in terms of ammonium discharge fluctuations but has higher aeration requirement. 


\section{Competing Interests}

The authors declare that they have no competing interests.

\section{References}

[1] A. I. Sviatenko and L. M. Korniyko, "Importance of the account of peculiarities of biological treatmentin aeration tanks for improvement of the indices of their operation," Environmental Safety-Kyiv State Ped. University, vol. 4, no. 8, pp. 93-96, 2009 (Ukrainian).

[2] D. Jenkins and J. Wanner, Activated Sludge-100 Years and Counting, IWA Publishing, London, UK, 2014.

[3] W. W. Eckenfelder and P. Grau, Activated Sludge Process Design and Control: Theory and Practice, Technomic, Chicago, Ill, USA, 1992.

[4] Metcalf and Eddy, Wastewater Engineering Treatment \& Reuse, 4th edition, 2002.

[5] C. Sahlmann, J. A. Libra, A. Schuchardt, U. Wiesmann, and R. Gnirss, "A control strategy for reducing aeration costs during low loading periods," Water Science and Technology, vol. 50, no. 7, pp. 61-68, 2004.

[6] M. Ekman, B. Björlenius, and M. Andersson, "Control of the aeration volume in an activated sludge process using supervisory control strategies," Water Research, vol. 40, no. 8, pp. 16681676, 2006.

[7] L. Åmand, G. Olsson, and B. Carlsson, "Aeration control-a review," Water Science \& Technology, vol. 67, no. 11, pp. 23742398, 2013.

[8] T. Shen, Y. Qiu, and H. Shi, "Mathematical simulation of feedforward control for nutrient removal in anaerobic-anoxicoxic processes," Environmental Engineering Science, vol. 27, no. 8, pp. 633-641, 2010.

[9] L. Rieger, I. Takács, and H. Siegrist, "Improving nutrient removal while reducing energy use at three Swiss WWTPs using advanced control," Water Environment Research, vol. 84, no. 2, pp. 170-188, 2012. 

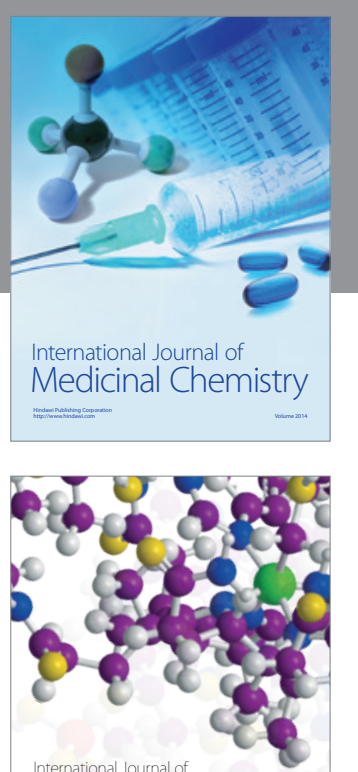

Carbohydrate Chemistry

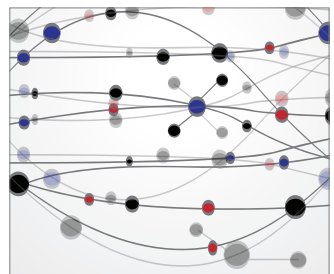

The Scientific World Journal
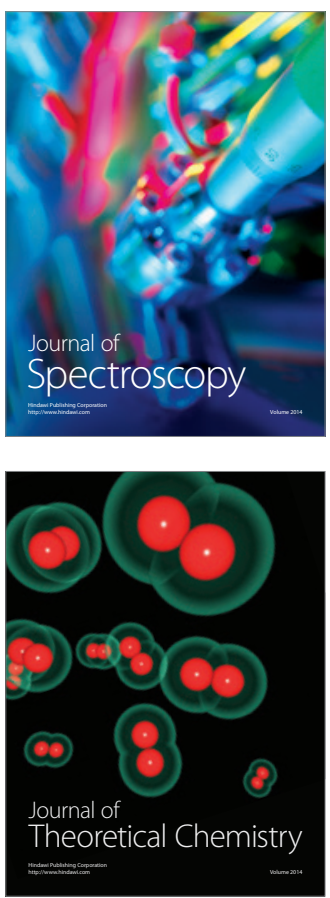
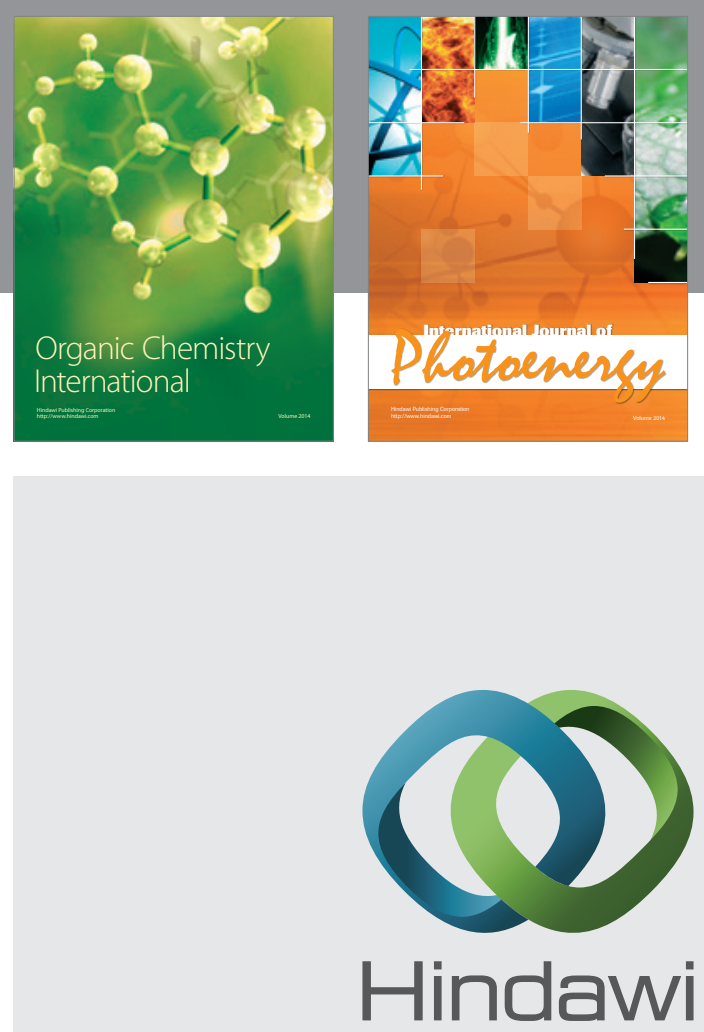

Submit your manuscripts at

http://www.hindawi.com

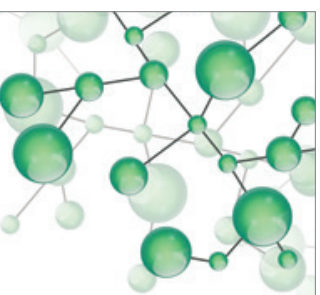

International Journal of

Inorganic Chemistry

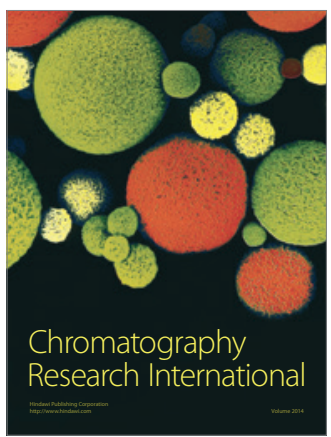

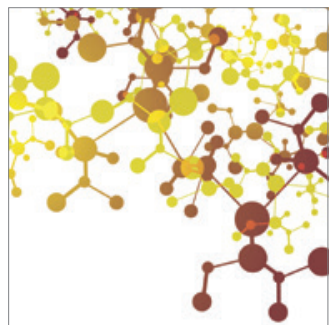

Applied Chemistry
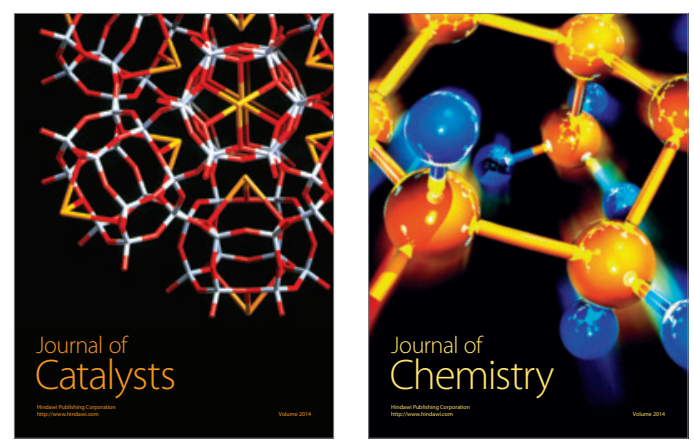
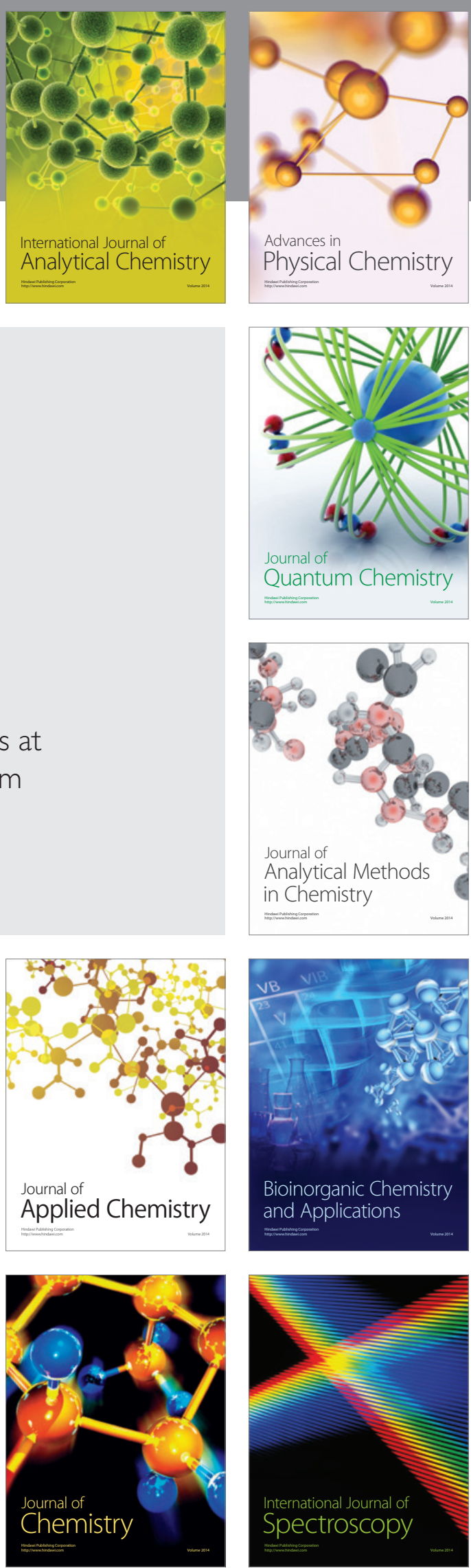